\title{
Antimicrobial Effect of Newly Formulated Toothpastes and a Mouthrinse on Specific Microorganisms: An In Vitro Study
}

\author{
Yeliz Guven ${ }^{1} \quad$ Nilufer Ustun ${ }^{1} \quad$ Elif Bahar Tuna ${ }^{1}$ \\ ${ }^{1}$ Department of Pedodontics, Faculty of Dentistry, Istanbul \\ University, Istanbul, Turkey
}

Eur J Dent 2019;13:172-177

\author{
Oya Aktoren ${ }^{1}$
}

\begin{abstract}
Address for correspondence Yeliz Guven, Istanbul University, Faculty of Dentistry, Department of Pedodontics, Capa 34093 Fatih, Istanbul, Turkey (e-mail: yguven@istanbul.edu.tr).
\end{abstract}

\begin{abstract}
Keywords

- antimicrobial activity

- Candida albicans

- mouthrinse

- Streptococcus mutans

- toothpaste

Objective The aim of this in vitro study was to assess the antimicrobial properties of newly formulated toothpastes (four toothpastes for adults and two toothpastes for kids/babies) and a mouthrinse.

Materials and Methods Newly formulated six different toothpastes and one mouthrinse of a single brand and commercially available five toothpastes and three mouthrinse were investigated for their antimicrobial activity against two oral pathogens, Streptococcus mutans and Candida albicans, by agar well diffusion assay. After incubation, the inhibition zone diameters were measured in millimeters and statistical analyses were performed.

Results All experimental adult toothpastes exhibited good antimicrobial activity against $S$. mutans and $C$. albicans except the experimental toothpaste D. Experimental toothpaste B exhibited the highest antibacterial activity against $C$. albicans and $S$. mutans. Experimental toothpaste for kids showed the best antimicrobial activity against S. mutans when kids' toothpastes were compared. None of the tested toothpastes for kids/babies showed antibacterial effects for $C$. albicans. Among the mouthrinse tested, Sensodyne mouthrinse showed the best results. Experimental mouthrinse showed significantly lower antibacterial activity against $S$. mutans then Sensodyne, Eludril, and chlorhexidine mouthrinse.

Conclusion Although experimental toothpaste and mouthrinse formulations revealed good results in terms of antimicrobial activity to some specific microorganisms, further studies involving more bacterial species or analyzing the quality and efficacy of these products by other in vitro or in vivo tests are needed.
\end{abstract}

\section{Introduction}

Dental caries is a localized, progressive, and transmissible bacterial disease caused by the acidic by-products of bacterial metabolism, which results in dissolution of the dental hard tissues. ${ }^{1}$ Dental plaque that is an oral microbial biofilm formed on dental surfaces is composed of a large variety of different oral microbial strains and species. Microbiological shifts and biochemical activities of complex microcommunities within the dental plaque result in dental caries. ${ }^{2}$ Streptococcus strains are the main group of microorganisms

DOI https://doi.org/

10.1055/s-0039-1695655

ISSN 1305-7456. associated with the caries process. Streptococcus mutans is one of the major cariogenic pathogens, which metabolizes fermentable carbohydrates and synthesizes an extracellular polysaccharide matrix that allows tight adherence of the organisms to the tooth surface and leads to the decalcification of the tooth structure. ${ }^{3,4}$ In addition to $S$. mutans, other microorganisms have been shown to be involved in the formation of cariogenic biofilms. Candida albicans is the most frequently yeast group isolated from the oral cavity and primarily associated with the mucosal infections (oral candidiasis) and denture-related stomatitis. ${ }^{5}$ Several studies report

License terms

() (1) $\ominus \circledast$ 
that it has been detected together with S. mutans in the dental plaque of children with carious teeth. ${ }^{6,7}$

Poor oral hygiene that leads to the accumulation of dental plaque on tooth surfaces is the main reason of carious lesions. The most effective measure for the prevention of plaque formation is the mechanical removal of dental plaque by regular tooth brushing, but its efficacy is highly dependent on the ability and cooperation of the individual..$^{89}$ Therefore, chemical plaque control agents such as toothpastes and mouthrinse should be used due to their potential role as a delivery system for antimicrobials. ${ }^{9,10}$ Various chemical agents such as triclosan, chlorhexidine (CHX), metal ions, and essential oils have been added to toothpastes and mouthrinse to provide antimicrobial activity. The antibacterial effect of fluoride is well established and depends on the influx of hydrogen fluoride into bacterial cells and the dissociation to the $\mathrm{H}^{+}$ and $\mathrm{F}^{-}$ions in the cytoplasm. Fluoride also has been known as an inhibitor of bacterial enzymes, such as adenosine triphosphatase and enolase. ${ }^{11}$ Despite the proven antibacterial efficiency of single chemical agents, this antibacterial activity may diminish or increase due to their interaction with other constituents in the toothpastes or mouthrinses. ${ }^{12}$ For instance, fluoride can be inactivated when calcium containing abrasives were used. Similarly, fluoride may react with silica to form fluorosilicates if a sufficient amount of detergent is not present. ${ }^{11}$ As a result, it is essential to examine every new toothpaste or mouthrinse formulations in their complete form. Therefore, the aim of this in vitro study is to assess the antimicrobial properties of newly formulated toothpastes (four toothpastes for adults and two toothpastes for kids) and a mouthrinse containing natural compounds.

\section{Materials and Methods}

Newly formulated oral hygiene products (six different toothpastes and one mouthrinse) developed by a single company and commercially available products of varying companies (five toothpastes and three mouthrinse) were investigated for their antimicrobial activity against two oral pathogens, S. mutans (RSKK 07038) and C. albicans (ATCC 10231) by agar well diffusion assay. The manufacturer's name and the ingredients of the toothpastes and mouthrinse evaluated in the present study are shown in - Table $\mathbf{1}$.

Experimental toothpastes were cultivated in Tryptic soy agar (TSA) (Merck), MacConkey agar (Merck), and yeast extract glucose chloramphenicol (YGC) agar (Merck) media to assess the microbial contamination before the antimicrobial activity test. TSA and MacConkey agar were incubated at $35^{\circ} \mathrm{C}$ for 24 hours, while YGC agar was at $25^{\circ} \mathrm{C}$ for 5 days. After the incubation period, no bacteria, yeast, or molds growth was observed in the samples. All mouthrinse and toothpastes were used at 1:1 dilution. Sterile deionized water was used as a negative control group in toothpaste and mouthrinse comparisons. A $0.2 \%$ solution of $\mathrm{CHX}$ digluconate was used as a positive control group when comparing mouthrinse.

S. mutans was cultivated in Columbia medium supplemented with 5\% sheep blood (COS medium, bioMérieux) and C. albicans was cultivated in Sabouraud 4\% dextrose agar.
Both were incubated at $32.5^{\circ} \mathrm{C} \pm 2.5^{\circ} \mathrm{C}$ for 44 to 52 hours. Fresh microorganism cultures were adjusted to McFarland $0.5\left(10^{8}\right)$ turbidity standards in $0.9 \% \mathrm{NaCl}_{2}$ solution. Nutrient agar plates were seeded with $100 \mu \mathrm{L}$ broth cultures of each isolate. Three wells per plate of $8 \mathrm{~mm}$ in diameter were prepared in each seeded agar plate and each well was filled with $50 \mu \mathrm{L}$ of the diluted solutions. The Petri dishes were incubated under the same growth conditions mentioned above. After the incubation period, the inhibition zones formed were measured in millimeters.

\section{Statistical Analysis}

The data were analyzed using SPSS 15.0 (IBM, Armonk, New York, United States) program. Kruskal-Wallis test was used for multiple comparisons and Mann-Whitney U-test was used in analyzing the differences between two groups.

\section{Results}

The results indicated that all toothpastes for adults were effective in inhibiting the growth of S. mutans and C. albicans, except Colgate anticavity with miswak toothpaste and experimental toothpaste $\mathrm{D}$ that did not produce inhibition zone for C. albicans (-Table 2). Experimental toothpaste D showed the lowest antibacterial effect against $S$. mutans among all groups. Experimental toothpaste B exhibited the highest antibacterial activity against $C$. albicans and $S$. mutans.

When the toothpastes for kids/infants were compared, experimental toothpaste for kids exhibited largest inhibition zone for S. mutans $(p<0.01)$ ( - Table 3). None of the tested toothpastes for kids/babies showed antibacterial effect for $C$. albicans.

All tested mouthrinse demonstrated a significant antimicrobial activity against $S$. mutans and C. albicans $(p<0.01)$, and the negative control showed no activity (-Table 4). Sensodyne mouthrinse showed the highest effect on $C$. albicans, while Listerine Zero mouthrinse showed the lowest effect on $S$. mutans $(p<0.05)$. Experimental mouthrinse showed significantly lower antibacterial activity against $S$. mutans than Sensodyne, Eludril, and CHX mouthrinse $(p<0.05)$. There was no significant difference between the levels of $S$. mutans and $C$. albicans in other mouthrinse $(p>0.05)$.

\section{Discussion}

It has been known that a sensitive bacterial balance exists in oral microflora and the loss of this balance results in emergence of potentially pathogenic bacteria and the initiation of disease process. ${ }^{13}$ Since $S$. mutans is the major pathogen involved in dental plaque and caries formation, it has been chosen as the main test organism in the present study. C. albicans, the most common fungal pathogen that is involved in candidiasis, systemic infections, and even dental caries, was chosen as another pathogen for testing. If a toothpaste or mouthrinse has good inhibition properties against $C$. albicans, then it can be recommended for the patients who is susceptible to oral fungal infections. ${ }^{14}$ 
Table 1 The tested products and their ingredients

\begin{tabular}{|c|c|c|}
\hline Product name & Manufacturer & Ingredients as listed on packages \\
\hline $\begin{array}{l}\text { Experimental } \\
\text { toothpaste } A \text { (for } \\
\text { sensitive teeth) }\end{array}$ & Biota Laboratory/Istanbul & $\begin{array}{l}\text { Glycerin, sorbitol, xanthan gum, stevia, abrasive silica, thickener silica, } \\
\text { titanium dioxide, sodium lauryl sulfate, potassium nitrate, clove oil, } \\
\text { miswak powder }\end{array}$ \\
\hline $\begin{array}{l}\text { Experimental tooth- } \\
\text { paste } B \text { (whitening } \\
\text { and stain removal) }\end{array}$ & Biota Laboratory/Istanbul & $\begin{array}{l}\text { Glycerin, sorbitol, xanthan gum, stevia, xylitol, abrasive silica, thicken- } \\
\text { er silica, titanium dioxide, sodium lauryl sulfate, mint flavor, miswak } \\
\text { powder }\end{array}$ \\
\hline $\begin{array}{l}\text { Experimental tooth- } \\
\text { paste C (anticavity) }\end{array}$ & Biota Laboratory/Istanbul & $\begin{array}{l}\text { Glycerin, sorbitol, xanthan gum, stevia, xylitol, abrasive silica, thicken- } \\
\text { er silica, titanium dioxide, sodium lauryl sulfate, mint flavor, miswak } \\
\text { powder, propolis extract }\end{array}$ \\
\hline $\begin{array}{l}\text { Experimental tooth- } \\
\text { paste D (anti-ade- } \\
\text { nomatous lesions) }\end{array}$ & Biota Laboratory/Istanbul & $\begin{array}{l}\text { Glycerin, sorbitol, xanthan gum, xylitol, abrasive silica, thickener silica, } \\
\text { titanium dioxide, cocamidopropyl betaine, sodium lauroyl sarcosinate, } \\
\text { mint flavor, miswak powder, liquorice, blackberry extract }\end{array}$ \\
\hline $\begin{array}{l}\text { Experimental tooth- } \\
\text { paste for kids }\end{array}$ & Biota Laboratory/Istanbul & $\begin{array}{l}\text { Glycerin, sorbitol, xanthan gum, stevia, xylitol, abrasive silica, thickener } \\
\text { silica, titanium dioxide, cocamidopropyl betaine, sodium lauroyl sarcos- } \\
\text { inate, miswak powder, caseine, preprobiotic }\end{array}$ \\
\hline $\begin{array}{l}\text { Experimental tooth- } \\
\text { paste for babies }\end{array}$ & Biota Laboratory/Istanbul & Glycerin, sorbitol, gellan gum, xylitol, silica, aroma \\
\hline $\begin{array}{l}\text { Colgate anticavity } \\
\text { toothpaste with } \\
\text { miswak }\end{array}$ & Colgate-Palmolive Co. & $\begin{array}{l}\text { Sodium monofluorophosphate } 1.1 \% \text {, calcium carbonate, aqua, sorbitol, } \\
\text { sodium lauryl sulfate, hydrated silica, aroma, cellulose gum, magne- } \\
\text { sium aluminum silicate, sodium carbonate, sodium saccharin, benzyl } \\
\text { alcohol, sodium bicarbonate, Commiphora myrrha oil, chamomilla } \\
\text { recutita flower extract, melaleuca alternifolia oil, salvia officinalis oil, } \\
\text { Salvadora persica, Mentha piperita oil, eucalyptus globulus oil, citrus } \\
\text { medica limonum oil, limonene, Cl 77492, Cl } 12085\end{array}$ \\
\hline $\begin{array}{l}\text { Sensodyne full } \\
\text { protection and whit- } \\
\text { ening toothpaste }\end{array}$ & GlaxoSmithKline & $\begin{array}{l}\text { Water, hydrated silica, sorbitol, glycerin, pentasodium triphosphate, } \\
\text { PEG-8, flavor, titanium dioxide, cocamidopropyl betaine, sodium meth- } \\
\text { yl cocoyl taurate, xanthan gum, sodium hydroxide, sodium saccharin, } \\
\text { sucralose, potassium nitrate }(5 \%) \text {, sodium fluoride }(0.15 \% \mathrm{w} / \mathrm{v} \text { fluoride } \\
\text { ion) }\end{array}$ \\
\hline $\begin{array}{l}\text { Sensodyne re- } \\
\text { pair and protect } \\
\text { toothpaste }\end{array}$ & GlaxoSmithKline & $\begin{array}{l}\text { Glycerin, PEG-8, Calcium sodium phosphosilicate (NOVAMIN), sodium } \\
\text { lauryl sulfate, sodium monofluorophosphate, aroma, titanium dioxide, } \\
\text { carbomer, potassium acesulfame, limonene } \\
\text { Contains sodium monofluorophosphate } 1.08 \% \text { w/w (1450 ppm } \\
\text { fluoride) }\end{array}$ \\
\hline $\begin{array}{l}\text { İpana Pro-Expert All } \\
\text { in One }\end{array}$ & Procter and Gamble Co. & $\begin{array}{l}\text { Aqua, sorbitol, hydrated silica, sodium lauryl sulfate, cellulose gum, } \\
\text { aroma, sodium gluconate, stannous chloride, carrageenan, Cl 77891, } \\
\text { zinc citrate sodium fluoride } 0.31 \%\end{array}$ \\
\hline $\begin{array}{l}\text { R.O.C.S kids } \\
\text { toothpaste }\end{array}$ & WSD Laboratory. & $\begin{array}{l}\text { Aqua, silica, glycerin, xylitol (10\%), olaflur, hydroxyethyl cellulose, poly- } \\
\text { sorbate-20, aroma, cocamidopropyl betaine, titanium dioxide, sodium } \\
\text { saccharin, methylparaben, propylparaben, potassium hydroxide, benzyl } \\
\text { alcohol, fluoride (500 ppm) }\end{array}$ \\
\hline $\begin{array}{l}\text { R.O.C.S baby } \\
\text { toothpaste }\end{array}$ & WSD Laboratory. & $\begin{array}{l}\text { Aqua, glycerin, xylitol (10\%), silica, chamomilla recutita (Matricaria) } \\
\text { flower extract, potassium (sodium) alginate, sodium benzoate, xanthan } \\
\text { gum }\end{array}$ \\
\hline $\begin{array}{l}\text { Experimental } \\
\text { mouthrinse }\end{array}$ & Biota Laboratory/Istanbul & $\begin{array}{l}\text { Glycerin, sorbitol, polysorbate } 20 \text {, stevia, poloxamer } 407, \text { CPC, mint } \\
\text { flavor, menthol, propolis extract, eucalyptol, thymol, chlorhexidine } \\
\text { digluconate }\end{array}$ \\
\hline $\begin{array}{l}\text { Listerine zero } \\
\text { mouthrinse }\end{array}$ & $\begin{array}{l}\text { Johnson and Johnson Cons. } \\
\text { Co }\end{array}$ & $\begin{array}{l}\text { Water, sodium fluoride } 0.02 \% \text {, sorbitol, propylene glycol, poloxamer } \\
407 \text {, sodium lauryl sulfate, flavor, sodium benzoate, phosphoric acid, } \\
\text { eucalyptol, methyl salicylate, thymol, sodium saccharin, menthol, diso- } \\
\text { dium phosphate, sucralose, red } 40 \text {, blue } 1\end{array}$ \\
\hline $\begin{array}{l}\text { Sensodyne } \\
\text { mouthrinse }\end{array}$ & GlaxoSmithKline Co. & $\begin{array}{l}\text { Aqua, glycerin, sorbitol, poloxamer } 338 \text {, PEG-60 hydrogenated castor } \\
\text { oil, potassium chloride, aroma, cetylpyridinium chloride, sodium } \\
\text { fluoride ( } 250 \text { ppm), methylparaben, propylparaben, sodium benzoate, } \\
\text { sodium saccharin, disodium phosphate, sodium phosphate }\end{array}$ \\
\hline $\begin{array}{l}\text { Eludril antibacterial } \\
\text { mouthrinse }\end{array}$ & Pierre Fabre Oral Care & $\begin{array}{l}\text { Glycerin, alcohol, aqua, aroma, benzyl alcohol, chlorhexidine digluco- } \\
\text { nate, chlorobutanol, Cl 16255, citral, citronellol, diethylhexyl sodium } \\
\text { sulfosuccinate, eugenol, limonene, linalool, menthol }\end{array}$ \\
\hline
\end{tabular}


Table 2 Zones of inhibition produced by adult toothpastes against Streptococcus mutans and Candida albicans

\begin{tabular}{|c|c|c|}
\hline & \multicolumn{2}{|c|}{ Mean \pm SD (median) } \\
\hline & $\begin{array}{l}\text { Streptococcus } \\
\text { mutans }\end{array}$ & $\begin{array}{l}\text { Candida } \\
\text { albicans }\end{array}$ \\
\hline $\begin{array}{l}\text { Colgate anti-cavity tooth- } \\
\text { paste with miswak }\end{array}$ & $\begin{array}{l}21.5 \pm 0.5 \\
(21.5)^{b, c, d, f, h, i}\end{array}$ & $\begin{array}{l}0 \pm 0 \\
(0)^{\text {b,c,d,e,f,g }}\end{array}$ \\
\hline $\begin{array}{l}\text { Sensodyne full protection } \\
\text { and whitening toothpaste }\end{array}$ & $\begin{array}{l}19.7 \pm 0.6 \\
(20)^{\mathrm{a}, \mathrm{d}, \mathrm{f}, \mathrm{g}, \mathrm{h}, \mathrm{i}}\end{array}$ & $\begin{array}{l}15 \pm 1 \\
(15)^{\mathrm{a}, \mathrm{c}, \mathrm{d}, \mathrm{g}, \mathrm{h}, \mathrm{i}}\end{array}$ \\
\hline $\begin{array}{l}\text { Sensodyne repair and protect } \\
\text { toothpaste }^{c}\end{array}$ & $\begin{array}{l}20 \pm 0 \\
(20)^{\mathrm{a}, \mathrm{d}, \mathrm{f}, \mathrm{g}, \mathrm{h}, \mathrm{i}}\end{array}$ & $\begin{array}{l}12.7 \pm 0.6 \\
(13)^{\mathrm{a}, \mathrm{b}, \mathrm{d}, \mathrm{f}, \mathrm{h}, \mathrm{i}}\end{array}$ \\
\hline Ipana Pro-Expert All in One ${ }^{d}$ & $\begin{array}{l}18.2 \pm 0.3 \\
(18)^{\mathrm{a}, \mathrm{b}, \mathrm{c}, \mathrm{e}, \mathrm{f}, \mathrm{g}, \mathrm{h}, \mathrm{i}}\end{array}$ & $\begin{array}{l}10 \pm 0 \\
(10)^{\mathrm{a}, \mathrm{b}, \mathrm{c}, \mathrm{f}, \mathrm{h}, \mathrm{i}}\end{array}$ \\
\hline $\begin{array}{l}\text { Experimental toothpaste A } \\
\text { (for sensitive teeth) }^{\mathrm{e}}\end{array}$ & $\begin{array}{l}21.3 \pm 1.2 \\
(22)^{\mathrm{d}, f, \mathrm{fh}, \mathrm{i}}\end{array}$ & $\begin{array}{l}11.7 \pm 2.9 \\
(10)^{\mathrm{a}, \mathrm{h}, \mathrm{i}}\end{array}$ \\
\hline $\begin{array}{l}\text { Experimental toothpaste } \\
\mathrm{B}(\text { whitening and stain } \\
\text { removal) }^{f}\end{array}$ & $\begin{array}{l}23.7 \pm 0.6 \\
(24)^{\mathrm{a}, \mathrm{b}, \mathrm{c}, \mathrm{d}, \mathrm{e}, \mathrm{h}, \mathrm{i}}\end{array}$ & $\begin{array}{l}15 \pm 0 \\
(15)^{\mathrm{a}, \mathrm{c}, \mathrm{d}, \mathrm{g}, \mathrm{h}, \mathrm{i}}\end{array}$ \\
\hline $\begin{array}{l}\text { Experimental toothpaste C } \\
\text { (anticavity) }\end{array}$ & $\begin{array}{l}22.7 \pm 0.6 \\
(23)^{b, c, d, h, i}\end{array}$ & $\begin{array}{l}11.3 \pm 1.2 \\
(12)^{\mathrm{a}, \mathrm{b}, \mathrm{f}, \mathrm{h}, \mathrm{i}}\end{array}$ \\
\hline $\begin{array}{l}\text { Experimental toothpaste D } \\
\text { (antiadenomatous lesions) }^{\mathrm{h}}\end{array}$ & $\begin{array}{l}12.3 \pm 0.6 \\
(12)^{\mathrm{a}, \mathrm{b}, \mathrm{c}, \mathrm{e}, \mathrm{f}, \mathrm{g}, \mathrm{i}}\end{array}$ & $\begin{array}{l}0 \pm 0 \\
(0)^{\text {b,c,d,e,f,g }}\end{array}$ \\
\hline Sterile deionized wateri & $\begin{array}{l}0 \pm 0 \\
(0)^{\mathrm{a}, \mathrm{b}, \mathrm{c}, \mathrm{d}, \mathrm{e}, \mathrm{f}, \mathrm{g}, \mathrm{h}}\end{array}$ & $\begin{array}{l}0 \pm 0 \\
(0)^{\mathrm{b}, \mathrm{c}, \mathrm{d}, \mathrm{e}, \mathrm{f}, \mathrm{g}}\end{array}$ \\
\hline$p$-Value & $0.003^{* *}$ & $0.005^{* *}$ \\
\hline
\end{tabular}

Abbreviation: SD, standard deviation.

Kruskal-Wallis test.

${ }^{* *} p<0.01$.

Note: Different superscript letters indicate statistical significance.

Table 3 Zones of inhibition produced by children toothpastes against Streptococcus mutans

\begin{tabular}{|c|c|}
\hline & $\begin{array}{l}\text { Streptococcus mutans, } \\
\text { mean } \pm \text { SD (median) }\end{array}$ \\
\hline R.O.C.S kids tooth paste ${ }^{a}$ & $9.3 \pm 0.6(9)^{b, c, d, e}$ \\
\hline R.O.C.S baby tooth paste ${ }^{b}$ & $0 \pm 0(0)^{a, c}$ \\
\hline Experimental toothpaste for kids ${ }^{c}$ & $16.8 \pm 1.9(16)^{\mathrm{a}, \mathrm{b}, \mathrm{d}, \mathrm{e}}$ \\
\hline $\begin{array}{l}\text { Experimental toothpaste for } \\
\text { babies }^{d}\end{array}$ & $0 \pm 0(0)^{\mathrm{a}, \mathrm{c}}$ \\
\hline Sterile deionized water ${ }^{\mathrm{e}}$ & $0 \pm 0(0)^{\mathrm{a}, \mathrm{c}}$ \\
\hline$p$-Value & $0.008^{* *}$ \\
\hline
\end{tabular}

Abbreviation: SD, standard deviation.

Kruskal-Wallis test.

${ }^{* *} p<0.01$.

Note: Different superscript letters indicate statistical significance.

The use of toothpaste as an adjunct to tooth brushing or the use of mouthrinse may assist to improve the effectiveness of oral hygiene practices in several ways. These include inhibiting the bacterial adhesion to tooth surface, reducing the overall rate of accumulation of plaque, and decreasing bacterial counts of saliva. ${ }^{15}$ Antimicrobial activity was assessed by the agar diffusion method that is based on the measurements of the microbial inhibition zones against the tested microorganisms. Diffusion phenomenon depends on physical and
Table 4 The mean values and standard deviations of the microbial inhibition zones induced by mouthrinse against Streptococcus mutans and Candida albicans

\begin{tabular}{|c|c|c|}
\hline & \multicolumn{2}{|c|}{ Mean \pm SD (median) } \\
\hline & $\begin{array}{l}\text { Streptococcus } \\
\text { mutans }\end{array}$ & $\begin{array}{l}\text { Candida } \\
\text { albicans }\end{array}$ \\
\hline Listerine zero mouthrinse $^{\mathrm{a}}$ & $8 \pm 0(8)^{b, c, d, e, f}$ & $0 \pm 0(0)^{b, e}$ \\
\hline Sensodyne mouthrinse ${ }^{b}$ & $11 \pm 0(11)^{a, d, f}$ & $\begin{array}{l}13 \pm 0 \\
(13)^{\mathrm{a}, \mathrm{c}, \mathrm{d}, \mathrm{e}, \mathrm{f}, \mathrm{f}}\end{array}$ \\
\hline $\begin{array}{l}\text { Eludril antibacterial } \\
\text { mouthrinse }{ }^{c}\end{array}$ & $\begin{array}{l}10.7 \pm 0.3 \\
(10.5)^{\mathrm{a}, \mathrm{d}, \mathrm{f}}\end{array}$ & $0 \pm 0(0)^{\mathrm{b}, \mathrm{e}}$ \\
\hline Experimental mouthrinse $^{d}$ & $10 \pm 0(10)^{b, c, e}$ & $0 \pm 0(0)^{\mathrm{b}, \mathrm{e}}$ \\
\hline Chlorhexidine digluconate & $11 \pm 0(11)^{\mathrm{a}, \mathrm{d}, \mathrm{f}}$ & $\begin{array}{l}14 \pm 0 \\
(14)^{\mathrm{a}, \mathrm{b}, \mathrm{c}, \mathrm{d}, \mathrm{f}}\end{array}$ \\
\hline Sterile deionized water ${ }^{f}$ & $0 \pm 0(0)^{\mathrm{a}, \mathrm{b}, \mathrm{c}, \mathrm{d}, \mathrm{e}}$ & $0 \pm 0(0)^{\mathrm{b}, \mathrm{e}}$ \\
\hline$p$-Value & $0.006^{* *}$ & $0.004^{* *}$ \\
\hline
\end{tabular}

Abbreviation: SD, standard deviation.

Kruskal-Wallis test.

${ }^{* *} p$-Value $<0.01$.

Note: Different superscript letters indicate statistical significance.

chemical properties of tested substance, such as the diffusion coefficient and the medium where the diffusion occurs. Moreover, bacteria colonized in the dental plaque have reduced sensitivity to antimicrobial agents compared with the planktonic bacteria. ${ }^{14,16}$ Therefore, this method can be used as a preliminary test for detecting antimicrobial activity in substances or products. The clinical relevance of these inhibition zones needs to be evaluated using in vivo models.

The largest inhibition zone for $S$. mutans was observed in experimental whitening and stain removal toothpaste. Three experimental toothpastes (whitening and stain removal, for sensitive teeth, anticavity types) and Colgate miswak showed higher antibacterial activity. These results can partly be attributed to the miswak content of the toothpastes. ${ }^{17} \mathrm{~A}$ review evaluating the therapeutic effects of miswak (Salvadora persica) has concluded that several studies investigating the antimicrobial activity of miswak found significant antibacterial effects against bacteria implicated in periodontitis and caries progression. ${ }^{18}$ On the contrary, Almas et al investigated the antimicrobial activity of 50\% miswak extract against seven microorganisms and concluded that miswak extract had mild antimicrobial activity against $S$. mutans. ${ }^{19}$ In the present study, another miswak containing toothpaste (experimental toothpaste D) showed the worst antibacterial activity against $S$. mutans. This controversial result may be explained by the fact that experimental toothpaste $\mathrm{D}$ contains cocamidopropyl betaine and sodium lauroyl sarcosinate instead of sodium lauryl sulfate that has a stronger antibacterial activity. Experimental toothpaste B and Sensodyne full protection and whitening toothpaste showed the largest inhibition zone for $C$. albicans compared with others. The ingredients such as titanium dioxide, xanthan gum, ${ }^{20}$ and miswak extract possess antifungal properties.

Inhibiting the growth of $S$. mutans in young children during the early phases of colonization may prevent its 
long-term establishment in the oral cavity. Therefore, tooth brushing with toothpastes containing compounds with antibacterial activity can contribute to the prevention of caries in children. ${ }^{21}$ In the present study, when children toothpastes were compared, only two of them (experimental toothpaste for kids and R.O.C.S kids toothpaste) were found to have antimicrobial activities. The antimicrobial activity of these products is due to the presence of ingredients such as fluoride, cocamidopropyl betaine, and sodium lauroyl sarcosinate. Toothpastes for babies that are free of these compounds did not show any antibacterial activity.

With respect to mouthrinse, Sensodyne mouthrinse showed the highest reduction in S. mutans counts. This may be due to the presence of cetylpyridinium chloride (CPC) as a major ingredient in its formulation. In a study by Latimer et al, CPC-containing mouthrinse, with and without fluoride, exhibited significant antibacterial efficacy against S. mutans. ${ }^{22}$ Watanabe et al investigated the antibacterial efficacy of a CPC-containing mouthrinse and found that all clinical isolates of mutans streptococci were inhibited by this product. ${ }^{23}$ Eludril antibacterial mouthrinse that contains CHX digluconate showed similarly high antibacterial activity against $S$. mutans. CHX has been demonstrated in in vivo and in vitro studies to reduce oral bacteria as well as inhibiting plaque formation and reducing gingivitis. ${ }^{24,25}$ Although the experimental mouthrinse has been expected to show high antibacterial activity, since it contains CHX digluconate and CPC in its formulation, significantly lesser antimicrobial activity than Sensodyne, Eludril, and the positive control group (CHX digluconate) was observed. This difference might be attributed to the differences in the CHX concentration and the modifications in the whole formulation that may have led to discrepancies among ingredients. ${ }^{25,26}$ Only Sensodyne mouthrinse and positive control group showed inhibitory effect against $C$. albicans. Although other mouthrinse contained ingredients such as CHX gluconate and CPC that have a proven efficacy against C. albicans, the lack of antifungal effect might be due to the fact that their effect may have been vitiated by another ingredient.

While the present study provides insight into the antimicrobial activity of the tested toothpastes and mouthrinse, certain limitations exist such as a limited number of tested microorganisms selected for this study. Furthermore, the test was conducted in vitro and the clinical implications were not investigated. It should be noted that in vitro results of antimicrobial efficacy may not be fully transferable to the oral cavity. Therefore, further studies should be conducted to find out the clinical efficacy of the tested toothpastes and mouthrinse that are not available commercially.

\section{Conclusion}

Based on the results of the present study, it can be concluded that all experimental adult toothpastes exhibited good antimicrobial activity against $S$. mutans and C. albicans except the experimental toothpaste developed for using in patients experiencing adenomatous lesions. With regard to kids/babies toothpastes, experimental toothpaste formulation prepared for kids showed the best antimicrobial activity against $S$. mutans. Among the mouthrinse tested, a conventionally available mouthrinse involving sodium fluoride and castor oil showed the best results. Although experimental toothpaste and mouthrinse formulations revealed good results in terms of antimicrobial activity to some specific microorganisms, further studies involving more bacteria species or analyzing the quality and efficacy of these products by other in vitro or in vivo tests are needed.

\section{Funding}

None.

\section{Conflict of Interest}

None declared.

\section{References}

1 Featherstone JD. Dental caries: a dynamic disease process. Aust Dent J 2008;53(3):286-291

2 Struzycka I. The oral microbiome in dental caries. Pol J Microbiol 2014;63(2):127-135

3 Koo H, Xiao J, Klein MI, Jeon JG. Exopolysaccharides produced by Streptococcus mutans glucosyltransferases modulate the establishment of microcolonies within multispecies biofilms. J Bacteriol 2010;192(12):3024-3032

4 Flemming HC, Wingender J. The biofilm matrix. Nat Rev Microbiol 2010;8(9):623-633

5 Iqbal Z, Zafar MS. Role of antifungal medicaments added to tissue conditioners: A systematic review. J Prosthodont Res 2016;60(4):231-239

6 Raja M, Hannan A, Ali K. Association of oral candidal carriage with dental caries in children. Caries Res 2010;44(3):272-276

7 Rozkiewicz D, Daniluk T, Zaremba ML, et al. Oral Candida albicans carriage in healthy preschool and school children. Adv Med Sci 2006;51(Suppl 1):187-190

8 Valkenburg C, Slot DE, Bakker EW, Van der Weijden FA. Does dentifrice use help to remove plaque? A systematic review. J Clin Periodontol 2016;43(12):1050-1058

9 Jafer M, Patil S, Hosmani J, Bhandi SH, Chalisserry EP, Anil $\mathrm{S}$. Chemical plaque control strategies in the prevention of biofilm-associated oral diseases. J Contemp Dent Pract 2016;17(4):337-343

10 Van der Weijden FA, Slot DE. Efficacy of homecare regimens for mechanical plaque removal in managing gingivitis a meta review. J Clin Periodontol 2015;42(Suppl 16):S77-S91

11 Ullah R, Zafar MS. Oral and dental delivery of fluoride: a review. Fluoride 2015;48:195-204

12 Auschill TM, Deimling D, Hellwig E, Arweiler NB. Antibacterial effect of two toothpastes following a single brushing. Oral Health Prev Dent 2007;5(1):25-32

13 Jenner F, Jaleel VA, Kulshrestha R, Maheswar G, Rao PK, Kranthi J. Evaluating the antimicrobial activity of commercially available herbal toothpastes on microorganisms associated with diabetes mellitus. J Contemp Dent Pract 2013;14(5):924-929

14 Lee SS, Zhang W, Li Y. The antimicrobial potential of 14 natural herbal dentifrices: results of an in vitro diffusion method study. J Am Dent Assoc 2004;135(8):1133-1141

15 Forssten SD, Björklund M, Ouwehand AC. Streptococcus mutans, caries and simulation models. Nutrients 2010;2(3):290-298

16 Randall JP, Seow WK, Walsh LJ. Antibacterial activity of fluoride compounds and herbal toothpastes on Streptococcus mutans: an in vitro study. Aust Dent J 2015;60(3):368-374 
17 Niazi F, Naseem M, Khurshid Z, Zafar MS, Almas K. Role of Salvadora persica chewing stick (miswak): a natural toothbrush for holistic oral health. Eur J Dent 2016;10(2):301-308

18 Haque MM, Alsareii SA. A review of the therapeutic effects of using miswak (Salvadora persica) on oral health. Saudi Med J 2015;36(5):530-543

19 Almas K, Skaug N, Ahmad I. An in vitro antimicrobial comparison of miswak extract with commercially available non-alcohol mouthrinses. Int J Dent Hyg 2005;3(1):18-24

20 Ruissen AL, van der Reijden WA, van't Hof W, Veerman EC, Nieuw Amerongen AV. Evaluation of the use of xanthan as vehicle for cationic antifungal peptides. J Control Release 1999;60(1):49-56

21 Evans A, Leishman SJ, Walsh LJ, Seow WK. Inhibitory effects of children's toothpastes on Streptococcus mutans, Streptococcus sanguinis and Lactobacillus acidophilus. Eur Arch Paediatr Dent 2015;16(2):219-226

22 Latimer J, Munday JL, Buzza KM, Forbes S, Sreenivasan PK, McBain AJ. Antibacterial and anti-biofilm activity of mouthrinses containing cetylpyridinium chloride and sodium fluoride. BMC Microbiol 2015;15:169

23 Watanabe E, Nascimento AP, Guerreiro-Tanomaru JM, Razaboni AM, de Andrade D, Tanomaru-Filho M. Antiseptic mouthwashes: in vitro antibacterial activity. Acta Odontol Latinoam 2015;28(2):180-184

24 Emilson CG. Potential efficacy of chlorhexidine against mutans streptococci and human dental caries. J Dent Res 1994;73(3):682-691

25 Herrera D, Roldán S, Santacruz I, Santos S, Masdevall M, Sanz M. Differences in antimicrobial activity of four commercial $0.12 \%$ chlorhexidine mouthrinse formulations: an in vitro contact test and salivary bacterial counts study. J Clin Periodontol 2003;30(4):307-314

26 Addy M, Jenkins S, Newcombe R. The effect of some chlorhexidine-containing mouthrinses on salivary bacterial counts. J Clin Periodontol 1991;18(2):90-93 